Artikel Penelitian

\title{
Uji Aktivitas Antibakteri Ekstrak Metanol dan Akuades Daun Ganitri (Elaeocarpus ganitrus Roxb.) Terhadap Bakteri Streptococcus mutans
}

\author{
Antibacterial activity of Elaeocarpus ganitrus leaf methanol and aquadest \\ extract against Streptococcus mutans
}

\author{
Naelaz Zukhruf Wakhidatul Kiromah*, Wahyu Rahmatulloh \\ Program Studi Farmasi, Sekolah Tinggi Ilmu Kesehatan Muhammadiyah \\ Gombong, Jl. Yos Sudarso No. 461 Gombong, Kebumen 54412, Indonesia \\ *E-mail: naela.zukhruf18@stikesmuhgombong.ac.id
}

\begin{abstract}
Abstrak
Streptococcus mutans merupakan bakteri yang dapat menyebabkan karies pada gigi. Tujuan penelitian ini adalah uji aktivitas antibakteri daun ganitri. Metode yang digunakan adalah difusi paper disk dengan konsentrasi ekstrak 10\%; $20 \%$; $30 \%$; $40 \%$; $50 \%$ dan $100 \%$. Hasil penelitian menunjukkan bahwa ekstrak metanol dengan konsentrasi $10 \%, 30 \%, 50 \%$ dan $100 \%$ memiliki daya hambat kategori kuat dengan zona hambat masing-masing $15.74 \mathrm{~mm}, 16.68 \mathrm{~mm}, 16.70 \mathrm{~mm}$ dan $17,68 \mathrm{~mm}$. Sedangkan ekstrak akuades pada konsentrasi $30 \%$ dan $100 \%$ memiliki zona hambat kategori sedang dengan diameter 11,04 dan 11,39 mm. Simpulan dari penelitian ini yaitu terdapat perbedaan diameter zona hambat yang signifikan pada setiap perlakuan. Hal ini menunjukkan bahwa ekstrak metanol memiliki daya hambat bakteri lebih baik daripada ekstrak akuades daun ganitri ( Elaeocarpus ganitrus Roxb).
\end{abstract}

Kata kunci: daun ganitri, difusi paper disk, streptococcus mutans

\begin{abstract}
Streptococcus mutans is responsible for cause the dental caries. The purpose of this research was to test antibacterial activity of Ganitrus leaves. The bacterial activity of methanol and aquadest by disc difusion method with $10 \% ; 20 \% ; 30 \% ; 40 \% ; 50 \%$ and $100 \%$. The extracts showed that methanol extract had activity with susceptible category at concentration of $10 \%, 30 \%, 50 \%$ and $100 \%$ against Streptococcus mutans with inhibition zone $15.74 \mathrm{~mm}, 16.68 \mathrm{~mm}, 16.70 \mathrm{~mm}$ and $17.68 \mathrm{~mm}$, respectively. Aquadest extract showed activity with intermediet category of $30 \%$ and $100 \%$ with inhibition zone $11,04 \mathrm{~mm}$ and $11,39 \mathrm{~mm}$. The methanol extract showed that activity of antibacterial better than the aqueous Elaeocarpus ganitrus Roxb levaes.
\end{abstract}

Keywords: ganitri leaf, paper disc diffusion, streptococcus mutans 


\section{PENDAHULUAN}

Gigi merupakan salah satu jaringan tubuh yang sangat mudah mengalami kerusakan. Prevalensi terjadinya masalah kesehatan gigi dan mulut menurut Hasil Riset Kesehatan Dasar (RISKESDAS) pada tahun 2018 sebanyak $57,6 \%$ masyarakat Indonesia mengalami masalah kesehatan gigi dan mulut (Kemenkes RI, 2018). Pembentukan karies gigi disebabkan beberapa faktor penting diantaranya yaitu mikroorganisme, host, makanan, dan waktu (Ramayanti, 2013).

Streptococcus mutans menjadi salah satu bakteri yang berperan penting dalam pebentukan karies gigi (Ningsih et al., 2016). Mekanisme terjadinya karies gigi menurut teori asidogenik karies gigi disebabkan akibat dari aktivitas mikoorganisme terhadap karbohidrat yang menghasilkan asam. Reaksi yang ditandai dengan dekalsifikasi komponen inorganik dilanjutkan desintegrasi substansi organik yang berasal dari gigi (Ramayanti, 2013).

Pengobatan maupun pencegahan pembentukan karies gigi secara umum dilakukan dengan menggunakan sikat gigi atau dengan menggunakan mouthwash, keduanya mengandung senyawa aktif chlorhexidine yang merupakan senyawa dari bahan kimia jika dalam penggunaannya dilakukan secara terus menerus akan menimbulkan efek samping berupa perubahan warna gigi, perubahan sensasi pengecapan hingga dapat membentuk kalkulus supragingival (Kasuma et al.., 2016).

Efek samping chlorhexidine dapat diminimalisir dengan mengganti senyawa yang berasal dari bahan sintetis dengan senyawa yang berasal dari bahan alam. Penggunaan bahan alam selain efek samping yang minimal, bahan yang digunakan mudah didapatkan dan mudah dalam penggunaanya (Novita, 2016). Daun ganitri merupakan salah satu tanaman yang memiliki potensi besar sebagai antibakteri dengan kandungan kimia berupa flavonoid, tanin, terpenoid dan steroid, saponin dan alkaloid (Pandey et al., 2016).

Kumar et al. (2011), mengungkapkan bahwa ekstrak akuades daun ganitri dapat menghambat pertumbuhan bakteri gram positif yaitu $S$. aureus, $B$. cereus dan $M$. luteus dengan hambatan maksimal pada bakteri $B$. cereus sebesar $15.6 \mathrm{~mm}$. Jayashree et al. (2016), menyatakan bahwa ekstrak aseton, metanol, dan air ganitri dapat menghambat pertumbuhan bakteri Staphylococcus aureus yang merupakan bakteri gram positif dengan hambatan pada konsentrasi $200 \mu \mathrm{g} / \mathrm{ml}$ sebesar $18,5 \mathrm{~mm}$.

Pandey et al. (2016), mengungkapkan bahwa ekstrak etanol dan metanol daun ganitri dapat menghambat pertumbuhan bakteri gram positif yaitu Staphylococcus aureus dan Bacillus subtilis dengan hambatan terbesar pada ekstrak metanol terhadap bakteri Staphylococcus aureus sebesar $20 \mathrm{~mm}$. Penelitian ini bertujuan untuk mengetahui aktivitas antibakteri dan perbedaan daya hambat antara ekstrak metanol dan akuades daun ganitri terhadap bakteri Streptococcus mutans.

\section{BAHAN DAN METODE}

Daun ganitri (Elaeocarpus ganitrus Roxb.) diambil dari wilayah Kabupaten Kebumen, Mueller Hinton Agar (MHA), metanol 70\%, akuades, cakram kertas, bakteri Streptococcus mutans, asam asetat, HCL, 
n-butanol, $\mathrm{FeCl}_{3}$, pereaksi meyer, dragendrof, wagner, Laminar Air Flow (LAF), inkubator, autoklaf, evaporator, blender, alat-alat gelas.

\section{Pembuatan simplisia}

Daun ganitri yang diperoleh dari Kabupaten Kebumen disortasi dengan mengambil daun yang berwarna hijau didapatkan berat sebanyak 2463 gram kemudian dicuci dengan air berih yang mengalir, dikeringkan dibawah sinar matahari dengan ditutup kain hitam, simplisia yang diperoleh dihaluskan dengan blender (Diniatik, 2015).

\section{Ekstraksi}

Pembuatan ekstrak metanol dan akuades dengan metode maserasi. Serbuk daun ganitri diambil sebanyak 200 gram untuk masing-masing pelarut dengan perbandingan pelarut 1:10. Selanjutnya didamkan selama 72 jam untuk pelarut metanol dan 24 jam untuk pelarut akuades dengan dilakukan sesekali pengadukan. Maserat yang diperoleh dikentalkan dengan evaporator pada suhu $40^{\circ} \mathrm{C}$ hingga diperoleh ekstrak kental (Pandey et al., 2016).

\section{Uji fitokimia}

Pemeriksaan fitokimia yang terkandung dalam ekstrak metanol dan akuades daun ganitri meliputi pemeriksaan fenol, flavonoid, tanin, saponin, triterpenoid dan steroid, glikosida dan alkaloid.

Pemeriksaan fenol

Sebanyak $50 \mathrm{mg}$ ekstrak di larutan dengan akuades kemudian ditetesi dengan larutan $\mathrm{FeCl}_{3}$ 5\%. Ekstrk dikatakan positif mengandung senyawa fenol jika timbul warna hijau kehitaman setelah ditetesi dengan larutan $\mathrm{FeCl}_{3}$ 5\% (Jayashree et al.., 2016).

\section{Pemeriksaan flavonoid}

Pada uji pereaksi basa, ekstrak daun ganitri dilarutkan dengan akuades, kemudian ditambahkan dengan beberapa tetes larutan $\mathrm{NaOH} 20 \%$ akan timbul warna kuning. Ekstrak positif mengandung senyawa flavonoid jika ditetesi dengan HCL warna kuning akan memudar (Talukdar et al., 2017).

Pada uji Wilstater, larutan ekstrak daun ganitri sebanyak $4 \mathrm{ml}$ dicampurkan dengan metanol 50\% sebanyak 1,5 ml. larutan dipanaskan ditambahkan logam magnesium. Ekstrak positif mengandung flavonoid jika larutan berubah menjadi warna orange atau merah setelah ditetsi HCL encer (Jayashree et al.., 2016).

Pemeriksaan tanin

Ekstrak dilarutkan pada akuades kemudian ditambahkan dengan beberapa tetes larutan $\mathrm{FeCl}_{3}$ 1\%. Ekstrak dikatakan positif mengandung senyawa tanin dengan timbulnya warna hitam atau biru kehijauan (Talukdar et al., 2017).

Pemeriksaan saponin

Ekstrak ganitri diambil sebanyak 0,5 gram ditambhkan dengan akuades sebanyak $5 \mathrm{ml}$ selanjutnya dikocok kuat. Ekstrak mengandung senyawa sapoin jika pada larutan terbentuk busa (Kumalasari et al., 2020). 
Pemeriksaan triterpenoid dan steroid

Reaksi Lieberman-Burchard dilakukan dengan mengambil sebanyak 0,5 gram ekstrak dilarutkan pada kloroform 0,5 ml, kemudian ditambahan dengan asam asetat anhidrat sebanyak $0,5 \mathrm{ml}$, sebanyak $2 \mathrm{ml}$ asam sulfat ditambahkan melalui dinding tabung. Ekstrak positif mengandung senyawa triterpenoid jika terbentuk cincin warna kecoklatan atau violet pada perbatasan larutan, serta positif mengandung steroid jika terdapat cincin warna biru kehijauan (Astarina et al., 2013).

Pemeriksaan glikosida

Ektrak diambil dan dilarutkan pada $5 \mathrm{ml}$ asam asetat anhidrat ditambahkan dengan asam sulfat pekat sebanyak 10 tetes. Ekstrak positif mengandung glikosida dengan timbulnya warna biru atau hijau (Simaremare, 2014).

Pemeriksaan alkaloid

Ekstrak diambil sebanyak 0,5 gram ditambahkan dengan HCL $2 \mathrm{~N}$ dan akuades sebanyak $9 \mathrm{ml}$, dipanaskan pada penangas air selama 2 menit, disaring dan filtrat diuji dengan pereaksi meyer jika positif mengandung alkaloid akan terbentuk endapan warna putih atau kuning, pada pereaksi dragendrof timbul warna jingga serta pada pereaksi wagner timbul warna coklat (Rachman et al., 2018).

Identifikasi senyawa dengan Kromatografi Lapis Tipis (KLT)

Identifikifasi menggunakan fase diam berupa silika gel $\mathrm{GF}_{254}$ dan fase gerak campuran $n$-butanol:asam asetat:air dengan perbandingan $3: 1: 1$, diamati pada spektrofotometri UV $254 \mathrm{~nm}$ dan $365 \mathrm{~nm}$. Pembanding yang digunakan berupa kuarsetin dan asam tanat. Senyawa fenol diidentifikasi dengan menyemprot plat KLT dengan penampak bercak $\mathrm{FeCl}_{3}$ ekstrak yang positif mengandung senyawa fenol akan menimbulkan warna hijau, merah, coklat, ungu, biru, atau hitam yang kuat (Tripathi et al., 2015).

\section{Inokulasi bakteri}

Bakteri uji diambil dari biakan murni kemudian digoreskan pada media agar miring yang telah disediakan dengan jarum ose steril, kemudian diinkubasi pada suhu $37^{\circ} \mathrm{C}$ selama 24 jam (Handayani et al., 2016)

\section{Suspensi bakteri}

Suspensi bakteri dibuat dengan mengambil biakan bakteri dan dimasukkan kedalam larutan $\mathrm{NaCl}$ 0,9\%, kemudian divortex dan dicocokan dengan larutan standar Mc. Farland (As'ari et al., 2016)

\section{Uji sensitivitas antibiotik}

Media diambil sebanyak $20 \mathrm{ml}$ kemudian dituangkan kedalam cawan petri steril didiamkan hingga dingin, kemudian ditambahkan suspensi bakteri sebanyak $1 \mathrm{ml}$, disk antibiotik yang sebelumnya direndam pada larutan amoxicillin, ciprofloxacin, dan kloramfenikol selama 15 menit kemudian diletakkan diatas media yang sudah ditambahkan suspensi bakteri uji dan diinkubasi selama 24 jam pada suhu $37^{\circ} \mathrm{C}$ (Muhammad et al., 2017).

Clear zone (zona hambat) yang diperoleh kemudian diukur dengan jangka sorong hasil pengukuran kemudian dibandingkan dengan tabel CLSI (Clinical Laboratory Standars Insitute) untuk menentuan antibiotik yang digunakan sensitif, intermediate dan resisten (Said, 2014). 


\section{Uji aktivitas antibakteri}

Uji daya hambat ekstrak etanol dan akuades dengan konsentrasi 10;20;30; 40; 50 dan $100 \% \mathrm{~b} / \mathrm{v}$ dengan metode yang digunakan yaitu difusi paper disk. Bakteri ditanam pada media MHA di cawan petri. Cawan petri diinkubasi pada suhu $37^{\circ} \mathrm{C}$ selama 24 jam. Percobaan direplikasi sebanyak 3 kali. Diameter zona bening yang didapatkan selanjutnya diukur dengan jangka sorong menggunakan rumus (Kristanti, 2014):

$R=\frac{p+q}{2}$

Keterangan:

$\mathrm{R}=$ Diameter zona hambat $(\mathrm{mm})$

$\mathrm{p} \quad=$ Diameter zona hambat terpanjang $(\mathrm{mm})$

$\mathrm{q}=$ Diameter zona hambat terpendek $(\mathrm{mm})$

Tabel 1. Kriteria diameter zona hambat (Surjowardojo et al., 2015)

\begin{tabular}{cc}
\hline Besaran Diameter & Kekuatan Hambatan \\
\hline$\geq 21 \mathrm{~mm}$ & Sangat kuat \\
$11-20 \mathrm{~mm}$ & Kuat \\
$6-10 \mathrm{~mm}$ & Sedang \\
$\leq 5 \mathrm{~mm}$ & Lemah \\
\hline
\end{tabular}

\section{Analisia data}

Uji aktivitas antibakteri diulang sebanyak 3 kali replikasi. Diameter zona hambat dinyatakan dalam rata-rata replikasi \pm standar deviasi (SD). Hasil pengujian dianalisis dengan one way Anova pada taraf kepercayaan 95\% dengan program spss versi 16 jika data tidak terdistribusi dengan normal maka analisis dilakukan dengan uji Kruskal wallis.

\section{HASIL}

\section{Ekstraksi}

Daun ganitri (Elaeocarpus ganitrus Roxb.) yang digunakan merupakan daun yang segar dan berwarna hijau. Daun yang telah dicuci bersih kemudian dijemur secara tidak langsung terhadap matahari. Hal ini dilakukan untuk menghindari pemanasan berlebih terhadap daun ganitri (Elaeocarpus ganitrus Roxb.). Metode maserasi dipilih untuk ekstraksi serbuk simplisia daun ganitri (Elaeocarpus ganitrus Roxb.) karena metode yang sederhana dan mampu mengekstraksi bahan-bahan yang tidak tahan terhadap pemanasan seperti daun. Pelarut yang digunakan adalah metanol $70 \%$ dan akuades karena kedua pelarut ini bersifat polar sehingga diharapkan dapat menarik senyawa aktif di dalam daun ganitri. Maserat dikentalkan dengan rotary evaporator. Ekstrak yang diperoleh ditimbang dan dihitung nilai rendemennya. Hasil yang didapatkan tersaji pada tabel 2.

Tabel 2. Hasil ekstraksi

\begin{tabular}{lcc}
\hline \multicolumn{1}{c}{ Parameter } & Metanol & Akuades \\
\hline Berat Simplisia (gr) & 200 & 200 \\
Berat Ekstrak (gr) & 63.59 & 46.75 \\
Rendemen (\%) & 31.79 & 23.38 \\
\hline
\end{tabular}




\section{Pemeriksaa fitokimia}

Ekstrak metanol dan akuades daun ganitri positif mengandung senyawa fenol dengan timbulnya warna hijau kehitaman. Senyawa flavonoid positif terkandung pada ekstrak metanol dan akuades dengan timbulnya warna kuning dan warna kuning akan memudar setelah ditetesi dengan HCL pekat pada uji pereaksi basa. Pada pengujian wilstater menunjukan hasil positif yang ditandai dengan timbulnya perubahan warna setelah ditambahkan dengan logam magnesium menjadi orange.

Tabel 3. Hasil skrining fitokimia

\begin{tabular}{|c|c|c|c|}
\hline \multirow{2}{*}{ Uji Fitokimia } & \multicolumn{2}{|c|}{ Ekstrak } & \multirow{2}{*}{ Keterangan } \\
\hline & Metanol & Akuades & \\
\hline Fenol & + & + & Hijau kehitaman \\
\hline \multicolumn{4}{|l|}{ Flavonoid } \\
\hline 1. Pereaksi basa & + & + & Kuning \\
\hline 2. Wilstater & + & + & Orange \\
\hline Tanin & + & + & Biru kehitaman \\
\hline Saponin & + & + & Timbul busa \\
\hline Triterpenoid & + & + & Cincin kecoklatan \\
\hline Steroid & - & - & - \\
\hline Glikosida & + & + & Hijau \\
\hline Alkaloid & - & - & - \\
\hline
\end{tabular}

Tanin positif terkandung pada ekstrak metanol dan akuades daun ganitri yang ditandai dengan timbulnya warna hitam. Pengujian saponin yang dilakukan membuktikan bahwa ekstrak metanol dan akuades positif mengandung senyawa saponin dengan timbulnya busa selama 10 menit setelah penggojogan. Pemeriksaan triterpenoid dan steroid ekstrak metanol dan akuades positif mengandung senyawa tritepenoid yang dibuktikan dengan timbulnya cincin kecoklatan pada perbatasan larutan sementara pada pengujian steroid tidak timbul warna biru kehijauan.

Pemeriksaan glikosida yang dilakukan dengan penambahkan sebanyak 10 tetes asam sulfat pekat dengan timbulnya warna hijau yang menandakan ekstrak positif senyawa glikosida. Sementara pada pemeriksaan alkaloid tidak terbentuknya endapan warna putih atau kuning pada pereaksi meyer, pada pereaksi dragendrof tidak timbul warna jingga dan pada pereaksi wagner tidak terdapat warna coklat.

\section{Identifikasi senyawa kromatografi lapis tipis}

Identifikasi KLT didapatkan Rf dengan nilai sebesar 0.89 noda 1 dan 0,98 noda 2 pada ekstrak metanol dengan perbandingan kuarsetin dengan nilai 0.98 dan asam tanat 0.95 ,pada ekstrak kuades dengan nilaiRf sebesar 0.88 pada nodal dan 0.91 pada noda 2 dengan pembanding kuarsetin 0.96 dan asam tanat 0.91 dari hasil perhitungan nilai Rf yang mendekati dengan pembandingnya maka ekstrak metanol dan akuades positif mengandung senyawa flavonoid dan tanin. Plat kromatogram disemprot dengan $\mathrm{FeCl}_{3}$ 
menunjukan warna hitam sehingga disimpulkan bahwa ekstrak positif mengandung senyawa fenol.

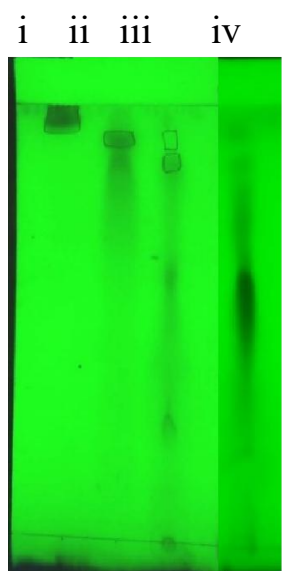

(a)

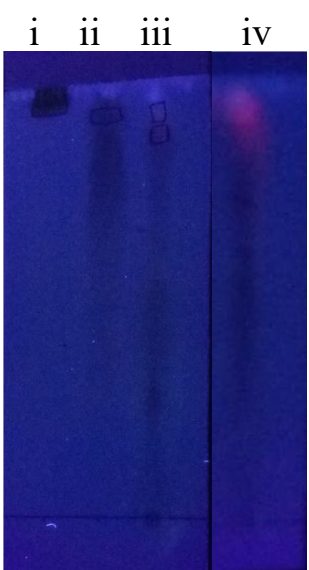

(b)

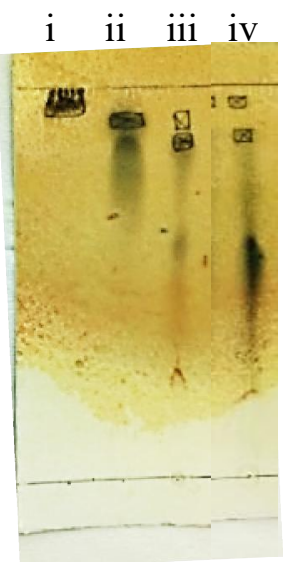

(c)

Gambar 1. Visualisasi plat kromatogram lapis tipis ekstrak metanol, dan akuades pada panjang gelombang $254 \mathrm{~nm}$ (a), $365 \mathrm{~nm}$ dan perekasi semprot $\mathrm{FeCl}_{3}$ (b). (i) kuarsetin (ii) asam tanat (iii) akuades (iv) metanol.

\section{Uji sensitivitas antibiotik}

Hasil uji sensitivitas antibiotik terhadap bakteri Streptococcus mutans dapat dilihat pada gambar 2 dan tabel 4. Uji sensitivitas pada penelitian ini menggunakan tiga antibiotik yaitu amoksisilin, siprofloksasi, dan kloramfenikol. Prinsip dari uji sensitivitas terhadap antibiotik adalah suatu kemampuan antibiotik dalam menghambat pertumbuhan bakteri Streptococus mutans secara in vitro, sehingga dapat dipilih sebagai kontrol positif pada penelitian ini. Pengujian sensitivitas antibiotik ini di bawah kondisi standar yang berpedoman pada Clinical and Laboratory Standards Institute (CLSI) (Soleha, 2015).

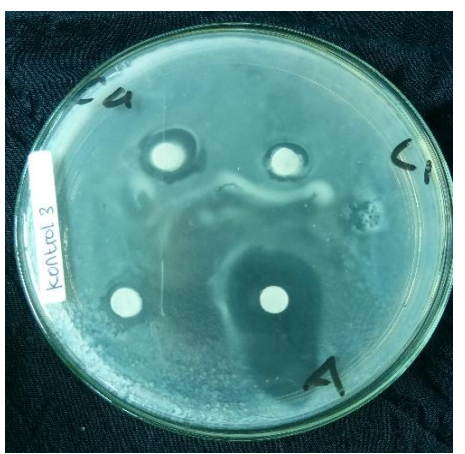

Gambar 2. Uji sensitivitas antibiotik amoksisilin (A), kloramfenikol (Ci), siprofloksasin (Ca) yang digunakan untuk menentukan sensitivitas antibiotik dalam menghambat pertumbuhan bakteri Streptococcus mutans. 
Tabel 4. Hasil Uji Sensitivitas

\begin{tabular}{lccccc}
\hline Senyawa & \multicolumn{2}{c}{$\begin{array}{c}\text { Standar diameter zona } \\
\text { hambat }(\mathrm{mm})\end{array}$} & $\begin{array}{c}\text { Diameter zona } \\
\text { hambat }(\mathrm{mm})\end{array}$ & Keterangan \\
& $\mathrm{S}$ & $\mathrm{I}$ & $\mathrm{R}$ & & \\
\hline Amoksisilln & $\geq 16$ & - & - & 20.72 & Sensitif \\
Siprofloksasin & - & -- & - & 11.54 & Resisten \\
Kloramfenikol & $\geq 21$ & $18-20$ & $\leq 15$ & 11.08 & Resisten \\
\hline
\end{tabular}

Berdasarkan tabel 4 menunjukan bahwa antibiotik amoxicillin mampu menghambat pertumbuhan bakteri Streptococcus mutans dengan diameter zona hambat sebesar $20.72 \mathrm{~mm}$ yang dikategorikan sensitif dan pada pengujian menggunakan antibiotik ciprofloxacin didapatkan nilai diameter hambatan sebesar $11.54 \mathrm{~mm}$ dan pada senyawa kloramfenikol didapatkan diameter zona hambat sebesar $11.08 \mathrm{~mm}$. Menurut tabel CLSI yang digunakan bahwa antibiotik siprofloksasin dan kloramfenikol dinyatakan resisten dalam menghambat pertumbuhan bakteri Streptococcus mutans.

\section{Uji Aktivitas Antibakteri}

Uji aktivitas antibakteri diperoleh bahwa ekstrak metanol dan akuades daun ganitri memiliki potensi yang dapat digunakan sebagai antibakteri. Ekstrak metanol dan akuades daun ganitri (Elaeocarpus ganitrus Roxb) menggunakan seri konsentrasi $10 ; 20 ; 30 ; 40 ; 50$ dan $100 \%$. Hasil uji aktivitas antibakteri ekstrak metanol dan akuades ditunjukkan pada gambar 3 dan 4. Gambar 3 menunjukkan bahwa ekstrak metanol dan akuades daun ganitri mempunyai aktivitas antibakteri terhadap Streptococcus mutans dengan terbentuknya diameter zona hambat (clear zone) setelah diinkubasi pada suhu $37^{\circ} \mathrm{C}$ selama 24 jam.

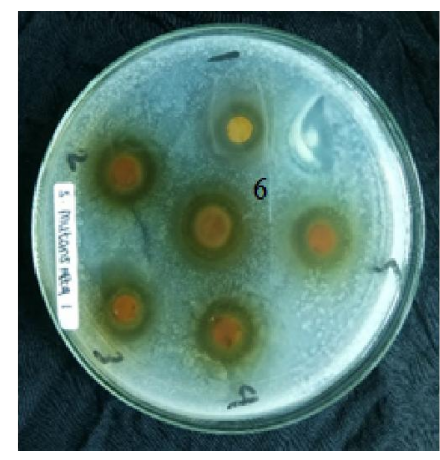

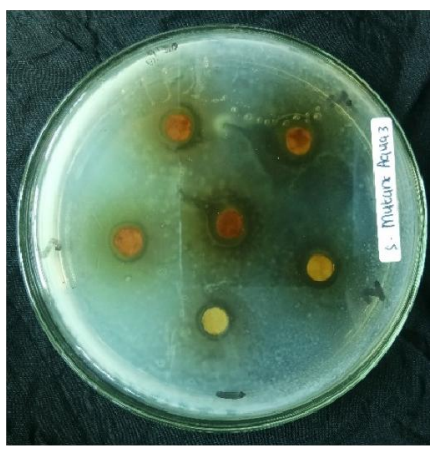

li

Gambar 3. Uji aktivitas antibakteri (i) ekstrak metanol dan (ii) ekstrak akuades 1. Konsentrasi $10 \%$, 2. Konsentrasi $20 \%$, 3. Konsentrasi $30 \%, 4$. Konsentrasi $40 \%$, 5. Konsentrasi $50 \%$, 6. Konsentrasi 100\% 


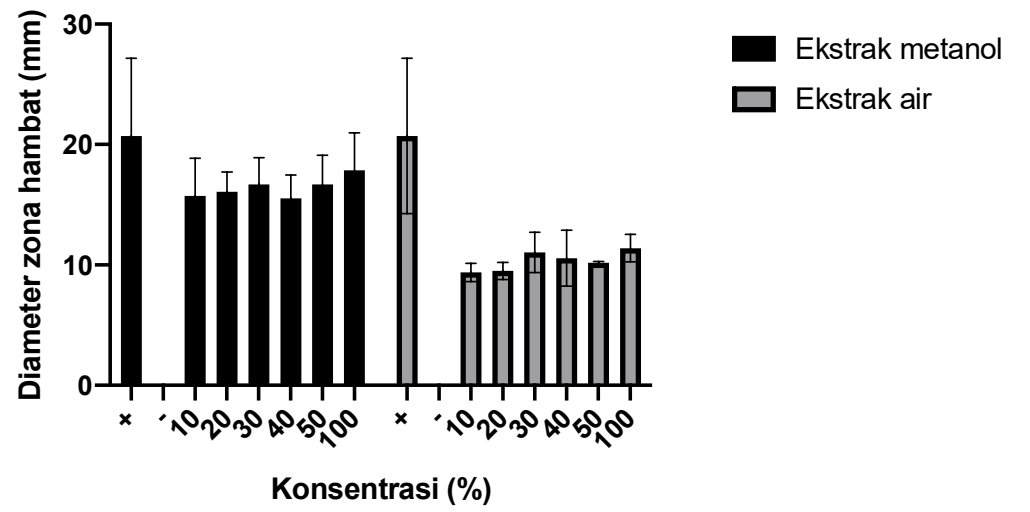

Gambar 4. Hasil uji aktivitas antibakteri ekstrak metanol dan akuades daun ganitri (Elaeocarpus ganitrus Roxb) terhadap bakteri Streptococcus mutans

Berdasarkan hasil uji aktivitas antibakteri ekstrak metanol dan akuades pada gambar 4 menunjukkan bahwa ekstrak metanol memiliki aktivitas antibakteri lebih baik daripada ekstrak akuades pada tiap konsentrasi. Pada gambar 4 juga menunjukkan bahwa pada konsentrasi 10\% ekstrak akuades menunjukkan aktivitas antibakteri dengan kategori kuat sebesar $15,74 \pm 3,11$. Sedangkan konsentrasi maksimal daya hambat ekstrak metanol adalah $100 \%$ dengan diameter zona hambat sebesar $17,86 \mathrm{~mm} \pm 3,10$. Hasil uji daya hambat terhadap bakteri Streptococcus mutans ekstak metanol apabila dibandingkan dengan kontrol positif, ekstrak metanol memiliki diameter zona hambat lebih kecil. Diamater zona hambat kontrol positif sebesar $20,72 \mathrm{~mm} \pm 6,45$.

\section{PEMBAHASAN}

Ekstrak metanol dan akuades memiliki aktivitas antibakteri terhadap bakteri Streptococcus mutans dengan terbentuknya diameter zona hambatan. Ekstrak metanol dan akuades daun ganitri memiliki nilai signifikansi sebesar $0.003 \leq 0.05$ yang artinya ekstrak metanol dan akuades dengan seri konsentrasi yang digunakan terdapat perbedaan yang signifikan dalam menghambat pertumbuhan bakteri streptococcus mutans.

Pandey (2016), mengungkapakan bahwa daun ekstrak daun ganitri mengandung senyawa aktif berupa flavonoid, tanin, saponin, triterpenoid, steroid dan alkaloid. Hal ini berbeda dengan hasil skrining fitokimia yang telah dilakukan dengan hasil bahwa ekstrak daun ganitri mengandung senyawa aktif berupa fenol, saponin, flavonoid, glikosida dan triterpenoid. Pandey (2015), menjelaskan bahwa kandungan senyawa aktif daun ganitri dipengaruhi oleh beberapa faktor yaitu lingkungan, iklim, fakorgenetik, dan faktor stres lingkungan (logam berat, elicator, sinar UV).

Diameter zona hambat yang terbentuk memiliki ukuran yang berbeda-beda dan cenderung semakin besar diameter zona hambat yang diperoleh seiring dengan semakin tinggi konsentrasi yang digunakan. Pada beberapa konsentrasi terdapat diameter zona hambat yang cenderung turun. Diameter zona hambat terbesar terdapat pada ekstrak metanol pada konsentrasi 100\% dengan nilai sebesar $17.68 \mathrm{~mm} \pm 3.10$. Madigan et al. dalam Lingga et al. (2016), mengungkapkan bahwa diameter zona hambat yang terbentuk 
dipengaruhi oleh beberapa faktor yaitu jumlah antibakteri yang diteteskan ke paper disk, daya larut antibakteri ke media, koefisien difusi, dan efektifitas antibakteri yang digunakan.

Parekh dalam Angelica (2013), mengungkapkan bahwa suatu ekstrak dikatakan memiliki potensi sebagai antibakteri dengan terbentuknya clear zone sebesar $1.4 \mathrm{~cm}$ atau lebih.

\section{SIMPULAN}

Ekstrak metanol memiliki daya hambat bakteri lebih baik daripada ekstrak akuades daun ganitri ( Elaeocarpus ganitrus Roxb). Ekstrak metanol pada konsentrasi 10\% menunjukkan aktivitas antibakteri dengan kategori kuat. Konsentrasi maksimal daya hambat antibakteri ekstrak metanol sebesar $100 \%$.

\section{REFERENSI}

Angelica, N. (2013). Aktivitas antibakteri ekstrak etanol daun dan kulit batang kayu manis (Cinnamomum burmannii (Nees \& Th. Nees)) Terhadap Escherichia coli dan Staphylococcus aureus. Calyptra: Jurnal Ilmiah Mahasiswa Universitas Surabaya, 2(2), 1-8.

As'ari, H., Kurnia, T. I. D., \& Nurchayati, N. (2016). Aktivitas Antimicrobial Ekstrak Etanol Biji Ganitri (Elaeocarpus sphaericus schum.) Terhadap Pertumbuhan Bakteri Patogen. Bioedukasi, $X I V(2), 14-18$.

Astarina, N. W. G., Astuti, K. W., \& Warditiani, N. K. (2013). Skrining Fitokimia Ekstrak Metanol Rimpang Bangle (Zingiber purpureum Roxb.). Jurnal Farmasi Udayana, 2(4).

Diniatik. (2015). Penentuan Kadar Flavonoid Total Ekstrak Etanolik Daun Kepel (Stelechorpus burahol (B1.) Hook f. \& Th.) Dengan Metode Spektrofotometri. Kartika-Jurnal Ilmiah Farmasi, II(1), 1-5.

Handayani, F., \& dkk. (2018). Formulasi Dan Uji Aktivitas Antibakteri Streptococcus mutans Dari Sediaan Mouthwash Ekstrak Daun Jambu Biji (Psidium guajava L.). Jurnal Sains Dan Kesehatan, 1(8), 74-84. https://doi.org/10.25026/jsk.v1i8.62

Jayashree, I., Geetha, D. H., \& Rajeswari, M. (2016). Evaluation of AntiMicrobial Activity of Elaeocarpus tuberculatus Roxb . AmericanEurasian J. Agric. \& Environ. Sci, 16(11), 1726-1731. https://doi.org/10.5829/idosi.aejaes.2016.1726.1731

Kasuma, N., Fajrin, F. N., Aldi, Y., \& Fitri, H. (2016). Pengaruh obat kumur ekstrak morinda citrifolia 1. sebagai antigingivitis. Dentika Dental Jounal, 19(2), 102-109. https://doi.org/10.32734

Kementerian Kesehatan RI. (2018). Hasil Utama Riskesdas 2018. Hal 96.

Kristanti, Karenia Ully Imaculata. (2014). Uji Aktivitas Antibakteri dari Ekstrak Tanaman Suruhan (Peperomia pellucida L.) Terhadap Pertumbuhan bakteri Escherichia coli dan Bacillus cereus Secara In-Vitro Serta Kaitannya Dengan Pembelajaran Biologi SMA Kelas X. Skripsi. Universitas Sanata Dharma.

Kumalasari, M. L. F., \& Andiarna, F. (2020). Uji Fitokimia Ekstrak Etanol Daun Kemangi (Ocimum basilicum L). Indonesian Journal for Health Sciences, 4(1), 39-44.

Kumar, G., Logananthan, K., \& Rao, K. B. (2011). Antimicrobial activity of 
Elaeocarpus ganitrus Roxb (Elaeocarpaceae): An in vitro Bio Technology Antimicrobial activity of Elaeocarpus ganitrus Roxb ( Elaeocarpaceae ): An in vitro study. Elixir Bio Technologi, 40(2014), 5384-5387.

Lingga, A. R., Pato, U., \& Rosi, E. (2016). Uji Antibakteri Ekstrak Batang Kecombrang (Nicolaia speciosa Horan) Terhadap Staphylococcus aureus dan Escherichia coli. JOM Faperta, 3(1), 99-102. https://doi.org/10.13581/j.cnki.rdm.20161021.001

Muhammad, A., Nurulita, nunuk aris, \& Budiman, A. (2017). Uji Sensitivitas Antibiotik Terhadap Bakteri Penyebab Infeksi Saluran Kemih Pada Pasien Rawat Inap di RSUD. Prof. Dr Margono Soekarjo Purwokerto. Pharmacy, 14(02), 247-263. https://doi.org/10.30595/pharmacy.v14i2.1684

Ningsih, S. U., Restuastuti, T., \& Endriani, R. (2016). Gambaran pengetahuan dan Sikap menyikat Gigi pada Siswa-Siswi Dalam mencegah Karies di SDN 005 Bukit Kapur dumai. Jom FK, 3(2), 111.

Novita, W. (2016). Uji Aktivitas Antibakteri Fraksi Daun Sirih (Piper betle L) Terhadap Pertumbuhan Bakteri Streptococcus mutans Secara Invitro. $J M J, 4(2), 140-155$.

Pandey, A., Misra, P., \& Trivedi, P. (2015). Constitutive Espression of Arabidopsis MYB Transcription Factor, AtMYB11, in Tobacco Modulates Flavonoid Biosynthesis in Favor o Flavonol Accumulation. Plant Cell Reports, 34, 1515-1528. https://doi.org/10.1007/s00299-015-1803-z

Pandey, K., Singh, M., Pandey, B., Upadhyaya, A., \& Pande, K. K. (2016). Preliminary phytochemical screening and antimicrobial activities of plant extract of Elaeocarpus ganitrus Roxb . International Journal Of Bioassays, 5(9), 4885-4889. https://doi.org/10.21746/ijbio.2016.09.0019

Rachman, A., Wardatun, S., \& Weandarlina, I. Y. (2015). Isolasi dan Identifikasi Senyawa Saponin Ekstrak Metanol Daun Binahong (Anredera cordifolia (Ten). Steenis). Journal Online Mahasiswa (JOM) Bidang Farmasi, 1(1), 1-6.

Ramayanti, S., \& Purnakarya, I. (2013). Peran Makanan terhadap Kejadian Karies Gigi. Jurnal Kesehatan Masyarakat, 7(2), 89-93. https://doi.org/https://doi.org/10.24893/jkma.v7i2.114

Said, A. (2014). Analisis pola kuman dan hasil kepekaan anti mikroba pada otitis media supuratif kronik di RSUP Dr. Wahidin Sudirohusododan RS Daya Makasar tahun 2013. Tesis. Universitas Hasanudin Makassar.

Simaremare, E. S. (2014). Skrining Fitokimia Ekstrak Etanol Daun Gatal (Laportea decumana (Roxb.) Wedd). Pharmacy, 11(01), 98-107. https://doi.org/10.30595/pji.v11i1.855

Soleha, T. U. (2015). Uji Kepekaan Terhadap Antibiotik. Juke Unila, 5(9), 120.

Surjowardojo, P., Susilorini, tri eko, \& Sirait, gabriel ruth batsyeba. (2015). Daya Hambat Dekok Kulit Apel Manalagi (Malus sylvestrs Mill.) Terhadap Pertumbuhan Staphylococcus aureus dan Pseudomonas sp. Penyebab Mastitis Pada Sapi Perah. Ternak Tropika, 16(2), 40-48. https://doi.org/10.21776/ub.jtapro.2015.016.02.6

Talukdar, N., Dutta, A., Chakraborty, R., \& Das, K. (2017). Screening Of Phytochemicals, Antioxidant And Inhibitory Effect On AlphaAmylase By Ethanolic Extract Of Elaeocarpus ganitrus (BARK). International Journal of Pharmaceutical Sciences And Research, 
8(12), 5270-5275. $\quad$ https://doi.org/10.13040/IJPSR.09758232.8(12).5270-75

Tripathi, Y. C., Shukla, P., \& Tewari, D. (2015). Phytochemical Evalution And Antihyperglycemic Effects of Elaeocarpus ganitrus Roxb (Rudraksha) In Streptozotocin Induced Diabetes. International Journal of Pharmaceutical Sciences, 7(1), 281-283.

\section{UCAPAN TERIMA KASIH}

Ucapan terimakasih disampaikan kepada Lembaga Penelitian dan Pengabdian Masyarakat Sekolah Tinggi Ilmu Kesehatan Muhammadiyah Gombong yang telah memberikan dukungan dana bagi penelitian ini

\section{KONTRIBUSI PENULIS}

NZWK merancang penelitian ini dan berkontribusi dalam pengumpulan data serta menyetujui versi akhir naskah. WR berkontribusi dalam pengumpulan data dan analisis statistik; dan semua penulis berkontribusi pada interpretasi data.

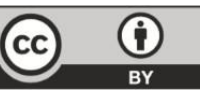

Akses Terbuka Artikel ini dilisensikan di bawah Creative Commons Lisensi Internasional Attribution 4.0, yang memungkinkan penggunaan, berbagi, adaptasi, distribusi, dan reproduksi dalam media atau format apa pun, selama Anda memberikan kredit yang sesuai kepada penulis asli dan sumbernya, memberikan tautan ke lisensi Creative Commons, dan menerangkan jika perubahan telah dilakukan. Gambar atau materi pihak ketiga lainnya dalam artikel ini termasuk dalam lisensi Creative Commons artikel, kecuali dinyatakan sebaliknya dalam batas kredit untuk materi tersebut. Jika materi tidak termasuk dalam lisensi Creative Commons artikel dan penggunaan yang Anda maksudkan tidak diizinkan oleh peraturan perundang-undangan atau melebihi penggunaan yang diizinkan, Anda harus mendapatkan izin langsung dari pemegang hak cipta. Untuk melihat salinan lisensi ini, kunjungi https://creativecommons.org/licenses/by/4.0/deed.id.

(C) The Author(s) 2020 